\title{
THE CORRELATION BETWEEN BUSINESS STRATEGY, INFORMATION TECHNOLOGY, ORGANISATIONAL CULTURE, IMPLEMENTATION OF CRM, AND BUSINESS PERFORMANCE IN A HIGH-TECH INDUSTRY
}

\author{
Y.C. Chung ${ }^{1 *}$, Y.W. Hsu ${ }^{2}$, S.C Tsai ${ }^{3}$, H.L. Huang ${ }^{4}$ \& C.H. Tsai ${ }^{5}$ \\ 1,2 Department of Industrial Engineering and Management \\ Ta-Hwa Institute of Technology, Taiwan \\ ${ }^{1}$ kent4321@ms19. hinet.net, ${ }^{2}$ ieywh@thit.edu.tw \\ ${ }^{3}$ Department of Food and Beverage Management \\ Yuanpei University, Taiwan \\ roland@mail.ypu.edu.tw \\ ${ }^{4}$ Department of Healthcare Management \\ Yuanpei University, Taiwan \\ hlhuang@mail.ypu.edu.tw \\ ${ }^{5}$ Department of Information Management \\ Yuanpei University, Taiwan \\ imtch@mail.ypu.edu.tw
}

\begin{abstract}
This paper studies the high-tech industry, probing the correlation between type of business strategy, use of information technology, type of organisational culture, implementation level of customer relationship management (CRM) activities, and business performance. Results show that the better the implementation of CRM activities, the stronger and more positive is its influence on business performance. To enhance business performance, it is necessary to strengthen the differentiation strategy, the use of information technology, and the implementation of CRM activities; to integrate the characteristics of the four cultural types into the competing values framework; and to enhance the implementation under these four cultural types.
\end{abstract}

\section{OPSOMMING}

In hierdie artikel word die korrelasie tussen die tipe ondernemingstrategie, die gebruik van inligtingtegnologie, die tipe organisasiekultuur, die implementeringsvlak van kliëntverhoudingsbestuur (CRM) en ondernemingsprestasie in hoë-tegnologie-ondernemings ondersoek. Die resultate toon dat beter kliëntverhoudingsbestuur ' $n$ poisitiewe invloed het op ondernemingsprestasie. Om ondernemingsprestasie te verbeter, is dit nodig om die differensiasie strategie, die gebruik van inligtingstegnologie asook die implementering van CRMaktiwiteite te versterk.

\footnotetext{
${ }^{1}$ The author was enrolled for a PhD (Management) degree in the Department of Technology Management, Chung Hua University, Taiwan.

${ }^{2}$ The author was enrolled for a PhD (Engineering) degree in the Department of Industrial Engineering and Engineering Management, National Tsing Hua University, Taiwan.

${ }^{3}$ The author was enrolled for a PhD (Education) degree at Idaho State University, USA.

${ }^{4}$ The author was enrolled for a PhD (Philosophy) degree in the College of Medicine, University of Manchester, UK.

${ }^{5}$ The author was enrolled for a PhD (Management) degree in the Department of Industrial Engineering Management, National Chiao Tung University, Taiwan.

* Corresponding author.
} 


\section{INTRODUCTION}

The high-tech industry has been the economic foundation of Taiwan. According to the document, "Criteria of study on export and import goods structures and classification" of the Republic of China's Ministry of Finance, any industry with a high added value of products, complicated techniques, and a high investment in technical manpower and R\&D funds, is treated as a high-tech industry. With technological progress, the life cycle of hightech products becomes shorter, while the reduction of product development and time to market is significant. Under pressure from a highly competitive environment, the emphasis of the business strategy in many firms is on how the high-tech industry selects a proper business strategy, uses information technology, and develops an organisational culture in its customer relationship management (CRM) activities to provide better products and service quality to customers and increase their business performance.

According to the research, a higher implementation level of CRM activities leads to a more significant and positive influence on business performance [8] [22] []40] [57] [58] [62]. A higher involvement of information technology leads to a more significant and positive influence on the implementation level of CRM activities [6] [11] [24] [46]; while different types of business strategy significantly - but differently - influence the implementation of CRM activities [24] [25] [29]. Different types of organisational culture significantly and positively influence the implementation level of CRM activities [1] [14] [30]. However, few of them include their business strategy, information technology involvement, and organisational culture in CRM activities to probe into their influence on their business performance. So this study examined the high-tech industry to explore the correlation among the type of business strategy, the use of information technology, the type of organisational culture, the implementation level of CRM activities, and business performance.

The purposes of this study were: (1) to probe the influence of the type of business strategy on the implementation level of CRM activities; (2) to examine the influence of information technology involvement on the implementation level of CRM activities; (3) to test the influence of the type of organisational culture on the implementation level of CRM activities; (4) to look into the influence of the implementation level of CRM activities on business performance; and (5) to offer suggestions about how the high-tech industry could implement CRM activities and increase business performance.

\section{LITERATURE REVIEW}

\subsection{Types of business strategy}

Porter [42] indicated that the competitive strategies of firms included cost leadership, differentiation, and centralisation. Miles \& Snow [33] divided business strategies into four types: (1) prospectors (value new products and new market development, and provide products with differentiation); (2) defenders (market segmentation focus on a limited niche market, and acquire competitive advantage by reducing cost and improving efficiency); (3) analysers (between prospectors and defenders, have rapid reaction by following prospectors in a changeable market and maintain original products and services in a stable market as defenders); (4) reactors (when encountering change in the environment, they lack complete planning and adaptation abilities, and passively and blindly respond to the pressure of the environment). According to Song et. al. [55], reactors are not able to respond to market change to fulfill the sustainable operation of their organisations, and this is a strategy without competitive advantage.

Durand \& Coeurderoy [17] divided business strategy into: (1) cost leadership (reduce prices of products or services by improving efficiency and reducing costs in order to acquire maximum business volume); (2) marketing differentiation (provide products and services different from other rivals; value product and service quality, innovation, and originality); (3) innovative differentiation (introduce innovative products and services that are not easily imitated by rivals to increase competitive advantage). This study treated cost leadership, 
marketing differentiation, and innovative differentiation (as proposed by Durand \& Coeurderoy [17]) as the defining elements in a high-tech industry business strategy.

\subsection{Information technology involvement}

Roberts [47] suggested that 'information technology' refers to all software and hardware tools that acquire, apply, display, save, and communicate information. According to Porter \& Miller [43], information technology should include information created and used by firms and technology to process information. Besides computers, it includes communication techniques, information identification devices, automated technology of plants, and other software- and hardware-related services. Lee [28] defined information technology involvement as resources and efforts invested by the organisation in order to accomplish the management function of information technology. Sakaguchi \& Dibrell [49] suggested that information technology involvement could be measured by information technology investment and training. Information technology investment is measured by quantitative measures on budgets and software and hardware devices. Information technology training refers to training personnel to use information technology. Chung et. al. [9] reviewed the relevant literature, and group information technology involvement into the following four dimensions: (1) perceptions of employees; (2) investment in hardware and software; (3) personnel training, and (4) the degree of information technology application. Miller \& Doyle [34] suggested that information technology involvement must be based on three aspects: (1) to probe into the importance of information technology in firms; (2) certain investment in software, hardware, and personnel to acquire benefits; (3) personnel training according to the needs of development personnel and users. Based on a literature review [9] [16] [28] [32] [34] [49] [54], this study divided information technology involvement into the perceptions of employees, investment in hardware and software, personnel training, and the degree of information technology application.

\subsection{Types of organisational culture}

Scholars define organisational culture differently. Tolfo \& Wazlawick [12] suggested that organisational culture is the values, beliefs, and regulations possessed and shared by the members of an organisation. Pekala [38] indicated that organisational culture is the regulated management of the members' behaviour. According to Lee \& Yu [27], organisational culture is the special atmosphere or belief created by the members of an organisation, and it could not be imitated by other organisations. Robbins [48] suggested that organisational culture is the important traits valued by the people in an organisation. These traits include the levels of innovation and adventure, demand for refinement, the value of results, the value of employees' perceptions, an emphasis on groups, a demand for employees' enthusiasm, and an emphasis on stability. The combination of the traits becomes the organisational culture. Jones \& George [19] suggested that organisational culture is the shared values, regulations, behavioural principles, and expectations influencing the interaction and cooperation between individuals, groups, and teams in the process of carrying out organisational goals.

As to the type of organisational culture, Wallach [60] divided organisational culture into bureaucratic, innovative, and supportive cultures. The competing values framework proposed by Quinn [45] includes four types of culture: rational, hierarchical, group, and developmental. According to Deshpande \& Farley [15], when employees describe the culture of their firms, they tend to describe the traits of rational, hierarchical, group, and developmental cultures; however, they would be inclined towards one of the cultures. This study adopted the rational, hierarchical, group, and developmental cultures framework of Quinn [45] to classify the organisational cultures of high-tech industries.

\subsection{Customer relationship management (CRM) activities}

Swift [57] suggested that CRM is a kind of operational model that allow firms to recognise and influence customers' behaviour by interaction with the customers, in order to acquire new customers, keep existing customers, increase customer loyalty, and enhance customer benefits. Peppard [40] suggested predicting and responding to customers' needs through information about current and potential customers; he also called it CRM. According to Bose 
[5], CRM is the integration between technology and business process, and it satisfies customers' needs through interaction. Kalakota \& Robinson [21] suggested that CRM is the consistent action of the organisation, developed through an integration of sales, marketing, and services in order to discover customers' real needs and enhance customer satisfaction and loyalty. According to Kandell [22], satisfying customers' needs is the core of CRM; it aims to retain customers and offer them different products and services; and it tries to increase customer satisfaction in order to acquire maximum benefits. Chen \& Popovich [7] suggested that CRM is the integration of people, processes, and skills; it aims to probe into a firm's customers, and focuses on customer maintenance and relationship development management. Peppers et. al. [41] suggested that CRM includes four steps: 1) recognise and probe into customers; 2) classify customers according to their different values; 3 ) respond differently to customers' demands; and 4) improve the cost benefit and effectiveness of interaction with customers, and provide different services for different customers.

Kalakota \& Robinson [20] suggested that the implementation of CRM activities includes three steps: obtain potential customers, increase current customers' profits, and maintain valuable customers. Swift [57] suggested that firms could implement CRM activities by four steps: knowledge discovery, marketing planning, customer interaction, and analysis and refinement. This study adopted the four steps of Swift [57] - knowledge discovery, marketing planning, customer interaction, and analysis and refinement - as the constructs for implementing CRM activities in high-tech industries.

\subsection{Business performance}

Croteau \& Bergeron [13] measured the performance of firms by their ability to make profits and by their sales growth. Shrader [52] measured business performance by profit rate and growth of sales. Farrell [18] suggested that business performance referred to the customer maintenance rate, new product success rate, growth of sales, return on investment, and overall performance of one firm compared with others. Baer \& Frese [2] treated the goal accomplishment rate of firms as a subjective measure of business performance. Tippins \& Sohi [59] measured organisational performance by profit rate, return on investment, customer maintenance rate, and growth of sales. Kirca et. al. [23] measured performance by overall business performance, profit rate, sales, and market share. Saraph et. al. [50] measured business performance based on customer satisfaction with quality over a three year period, and on performance quality. Baker \& Sinkula [3] probed the influence of innovative activities on corporate performance by measuring sales revenue, market share, and profit rate. Slater \& Narver [53] evaluated the performance of firms by return on investment. In the research of Su et. al. [56], business performance is measured by a firm's profits and customer satisfaction. Pelham [39] measured the performance of firms through corporate efficiency, growth and market share, and ability to make a profit.

Based on the literature review and on the characteristics of high-tech industries, this study has adopted profit rate, growth of sales, product and service quality, customer maintenance rate, successful new product to market, and return on investment as measures of performance in the high-tech industry.

\subsection{Types of business strategy and CRM activities}

Ko et. al. [25] suggested that a firm's business strategy influences the implementation of CRM activities. According to Lin [29], the selection of a business strategy significantly influences the implementation level of CRM activities. Ko et. al. [24] suggested that different types of organisational business strategy significantly and differently influence the implementation of CRM activities.

Based on the literature review above, this study proposes $\mathrm{H}_{1}$ : Different types of business strategy significantly and differently influence the implementation of CRM activities.

\subsection{Information technology involvement and CRM activities}

Cooper et. al. [11] suggested that information technology plays a critical role in CRM activities. Information technology can integrate customer information and create useful 
knowledge about customers that enhances the maintenance of the relationship with them. Caldwell [6] suggested that the key to CRM activities is to create a close relationship between a firm and its customers. The application of Information technology results in a more efficient and closer interaction between a firm and its customers. Shoemaker [51] indicated that CRM is the technology that combines sales, marketing, and service information systems to construct a partnership with customers. Ko et. al. [24] suggested that the maturity of an information system would influence the implementation level of CRM activities. Krishnan et. al. [26] indicated that companies increasingly provide customers with information technology-based services in order to increase product and service quality, customer satisfaction, productivity, and financial performance. Ratcliff [46] suggested that CRM is a concept based on marketing, and that it can effectively maintain and enhance the relationship between firms and their customers. Information technology supports CRM, and it results in the efficient implementation of CRM activities.

Based on the literature review above, this study proposes $\mathrm{H}_{2}$ : A higher level of information technology involvement leads to a more significant and more positive influence on the implementation level of CRM activities.

\subsection{Types of organisational culture and CRM activities}

Agarwal et. al. [1] suggested that organisational culture is critical to the implementation level of CRM activities. Van Bentum \& Stone [4] indicated that organisational culture significantly influences the implementation of CRM activities. According to Curry \& Kkolou [14], the construction of a customer-based culture with participation and team work would enhance the implementation of CRM activities. Li [30] suggested that it is necessary to create an appropriate organisational culture in order to reduce obstacles to the implementation of CRM activities.

Based on the literature review, this study proposes $\mathrm{H}_{3}$ : Different types of organisational culture significantly and differently influence the implementation of CRM activities.

\subsection{CRM activities and business performance}

Kandell [22] indicated that CRM activities aim to satisfy customers' needs, maintain customer loyalty, provide different products and services, try to enhance customer satisfaction, and acquire maximum business benefits. Yim et. al. [62] indicated that the implementation of CRM can increase customer satisfaction and loyalty. In turn, a firm's business performance increases along with customer satisfaction and loyalty. According to Christy et. al. [8], the implementation of CRM can increase profits and the market share of products or services. Swift [57] indicated that CRM is the operational model that allows firms to probe into and influence customers' behaviour by interaction with them, and to enhance customer loyalty and customers' profit rate. Peppard [40] indicated that the advantages of maintaining positive a relationship with customers include an increased customer retention rate, feedback from customers, meeting customers' expectations, and retaining customers, thus increasing profits. Tiwana [58] indicated that the implementation of CRM activities helps firms to improve customer relationships and obtain more profits from their original customers.

Based on the literature review above, this study proposes $\mathrm{H}_{4}$ : A higher implementation level of CRM leads to a more significant and positive influence on business performance.

\section{RESEARCH METHODS}

This study intended to probe the correlations between type of business strategy, information technology involvement, type of organisational culture, CRM activities, and business performance in the high-tech industry. The research framework is shown in Figure 1.

\subsection{Research hypotheses}

Based on the literature review, the hypotheses are: 
$\mathrm{H}_{1}$ : Different types of business strategy significantly and differently influence the implementation of CRM activities.

$\mathrm{H}_{2}$ : A higher level of information technology involvement leads to more significant and positive influence on the implementation level of CRM activities.

$\mathrm{H}_{3}$ : Different types of type of organisational culture significantly and differently influence the implementation of CRM activities.

$\mathrm{H}_{4}$ : A higher implementation level of CRM activities leads to a more significant and positive influence on business performance.

\section{Business strategy \\ 1. Cost leadership \\ 2. Marketing differentiation \\ 3. Innovative differentiation}

\section{Information technology} involvement

1. Perception of employees

2. Investment in software \& hardware

3. Personnel training

4. Degree of information technology application

\section{Organisational culture}

1. Rational culture

2. Hierarchical culture

3. Group culture

4. Developmental culture

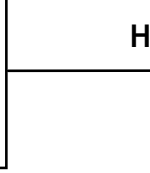

$\mathrm{H}_{1}$

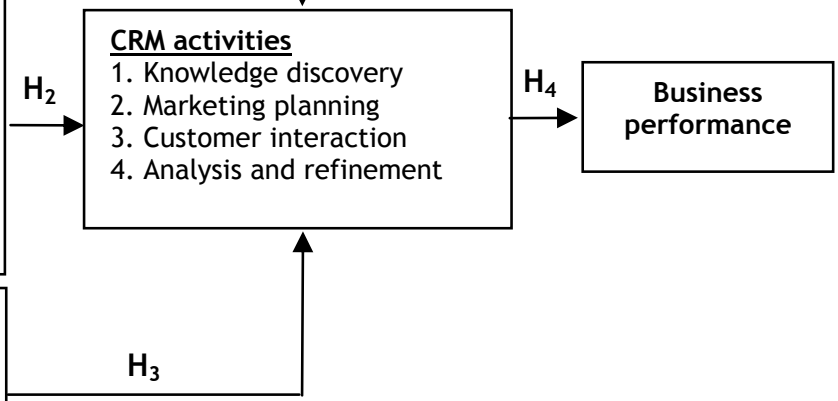

Figure 1: Research framework

\subsection{Questionnaire collection and data analysis}

The questionnaire used in this study consists of six sections. The first section is about the industry group and enterprise scale. 'Industry group' includes: integrated circuit industry, computer and related industry, communication industry, photoelectric industry, precision machinery industry, and biotechnology industry. According to the number of employees, 'enterprise scale' is divided into large, medium, and small firms.

Sections 2 6 are measured using a Likert 5-point scale.

- Section 2: Types of business strategy include (1) cost leadership; (2) marketing differentiation; (3) innovative differentiation.

- Section 3: Information technology involvement includes (1) perceptions of employees; (2) investment in hardware and software; (3) personnel training; (4) the degrees of information technology application.

- Section 4: Types of organisational culture include (1) rational culture; (2) hierarchical culture; (3) group culture; (4) developmental culture.

- Section 5: Implementation level of CRM activities includes (1) knowledge discovery; (2) marketing planning; (3) customer interaction; (4) analysis and refinement.

- Section 6: Business performance includes profit rate, growth of sales, product and service quality, customer maintenance rate, successful new products to market, return on investment.

The subjects of this research were high-tech firms in the Science-Based Industrial Parks of Hsinchu, Central Taiwan, and Southern Taiwan. The questionnaires were anonymous, and were distributed to 629 companies in early November 2010. The respondents were senior managers. A total of 78 effective samples were collected by January 2011. Nunnally [36] suggested that in an exploratory study, a reliability greater than 0.7 is acceptable. All the 
reliability variables of this study are above 0.7 , so the results carry sufficient reliability. Table 1 shows the reliability values. Data analysis of this study is based on SPSS for Windows, and the main statistical analysis is the analysis of variance.

\begin{tabular}{llc}
\hline Questionnaire elements & Cronbach's a \\
\hline Business strategy & Cost leadership & 0.841 \\
& Marketing differentiation & 0.900 \\
& Innovative differentiation & 0.779 \\
\hline Information technology & Perception of employees & 0.886 \\
involvement & Investment in hardware and software & 0.936 \\
& Personnel training & 0.879 \\
& Degree of information technology application & 0.919 \\
\hline Organisational culture & Rational culture & 0.839 \\
& Hierarchical culture & 0.705 \\
& Group culture & 0.926 \\
& Developmental culture & 0.934 \\
\hline CRM activities & Knowledge discovery & 0.877 \\
& Marketing planning & 0.924 \\
& Customer interaction & 0.927 \\
\hline Business performance & Analysis and refinement & 0.952 \\
\hline
\end{tabular}

Table 1: Cronbach's a coefficients for all variables

\subsection{Measurement of variables}

The variables include type of business strategy, information technology involvement, type of organisational culture, implementation level of CRM activities, business performance, industry group, and enterprise scale. The measurement of the variables is shown below:

\subsubsection{Measurement of type of business strategy}

This study used cost leadership, marketing differentiation, and innovative differentiation, as proposed by Durand \& Coeurderoy [17], to classify business strategy. According to empirical questionnaires developed by previous studies [17, 31, 35, 44, 61] and the business characteristics of the high-tech industry, the elements of business strategy are as follows:

- Cost leadership. It includes (a) investment in techniques or equipment that can save costs; (b) limit cost of production or services to lower levels; (c) reduce cost by improving business and services; (d) make efforts to decrease costs in order to provide products and services with prices lower than those of rivals.

- Marketing differentiation. It includes (a) efforts to offer products and services with more value than those of rivals; (b) according to customers' different needs, firms provide proper products and services; (c) firms make an effort to provide products and services of a higher quality and better characteristics than those of rivals.

- Innovative differentiation. It includes (a) making it difficult for rivals to imitate the firm's products and services; (b) providing better products and services than rivals by re-designing service content; (c) providing better products and services than rivals through new techniques or approaches.

The measurement is based on a Likert 5-point scale, where 'Strongly agree' is 5 points, 'Agree' is 4 points, 'Fair' is 3 points, 'Disagree' is 2 points, and 'Strongly disagree' is 1 point.

\subsubsection{Information technology involvement}

The measurements for information technology involvement are modified from Chung et. al. [9]. This study divided information technology involvement into four dimensions: perception of employees, investment in hardware and software, personnel training, and degree of information technology application.

- Perception of employees. It includes (a) the firm's support for information technology involvement; (b) employees' recognition of the importance of information technology;

(c) employees' high acceptance of information technology. 
- Investment in hardware and software. It includes (a) firms have sufficient funds in information technology; (b) firms invest in sufficient information technology software; (c) firms invest in sufficient information technology hardware.

- Personnel training. It includes (a) employees receive sufficient training in information technology; (b) employees are familiar with the use of information technology; (c) firms have adequate professional information technology personnel; (d) firms have complete teaching materials and manuals for the information system.

- Degree of information technology application. It includes (a) employees support CRM activities through information technology; (b) employees support business by applying information technology; (c) firms deliver important information to employees through information technology; (d) firms construct a complete communication network with customers and suppliers using information technology; (e) firms transform collected data into useful information using information technology.

The measurement is based on a Likert 5-point scale, where 'Strongly agree' is 5 points, 'Agree' is 4 points, 'Fair' is 3 points, 'Disagree' is 2 points, and 'Strongly disagree' is 1 point.

\subsubsection{Measurement of type of organisational culture}

The organisational culture scale in this study is based on a modification of the 'organisational culture diagnosis questionnaire' designed by Quinn [45], following the competing values framework and organisational culture measurement of Deshpande \& Farley [15], Chung et. al. [10], and Parker \& Bradley [37]. Four types of organisational culture are identified:

- Rational culture. It includes (a) firms value job performance and completion of tasks; (b) leaders of firms play the role of instructor to stimulate employees to accomplish the firms' goals; (c) cohesion of firms is based on job performance and accomplishing tasks; (d) the 'organisational atmosphere' of firms refers to competition and the value placed on achievement; (e) firms' rewards for employees will be according to their accomplishing of job goals or performance.

- Hierarchical culture. It includes (a) firms are formal organisations with specific levels, and everyone's job is regulated in detail; (b) leaders of firms expect employees to do their job according to the rules, policies, or procedures; (c) cohesion of firms is based on laws, regulations, and policies that aim to maintain the organisation's operation; (d) firms emphasise stability and the efficiency of stable operations; (e) firms reward employees according to their position or level in the organisation.

- Group culture. It includes (a) the firm emphasizes human values, and resembles a big family; (b) leaders are like teachers and good friends who help employees to develop their potential; (c) cohesion is based on loyalty and mutual trust; (d) firms value human resources, emphasise team work, and encourage employees' morale; (e) firms treat every employee equally and offer fair rewards.

- Developmental culture. It includes (a) firms encourage innovation, and employees are willing to take risks and face challenges; (b) leaders of firms encourage employees to take risks and innovate; (c) cohesion of firms is based on innovation and R\&D; firms make efforts to become leaders in the market; (d) firms value growth, acquire new resources, and are prepared for new challenges at any time; (e) rewards for employees will be according to employees' originality or plans.

The measurement is based on a Likert 5-point scale, where 'Strongly agree' is 5 points, 'Agree' is 4 points, 'Fair' is 3 points, 'Disagree' is 2 points, and 'Strongly disagree' is 1 point.

\subsubsection{Measurement of implementation of CRM activities}

This study used the four steps (knowledge discovery, marketing planning, customer interaction, and analysis and refinement) proposed by Swift [57] as elements in the implementation of CRM activities. Based on the business characteristics of the high-tech industry, the implementation of CRM activities is generalised below:

- Knowledge discovery. It includes (a) recognise specific market and investment opportunities by analysing customers' information; (b) make better decisions by analysing past data and customers' characteristics; (c) recognise, segment and predict 
customers in order to allow firms to distribute resources to customers who make high contribution to profits.

- Marketing planning. It includes (a) plan marketing plans by analysing customers' information; (b) design marketing or service activity types according to customers' reactions; (c) plan an effective model for communication with customers; (d) recognise effective marketing channels to increase business; (e) discover factors of business interaction between customers and firms.

- Customer interaction. It includes (a) constant interaction with customers through information software or systems equipment; (b) interact with customers via various channels; (c) detect customers' reactions and constantly update information.

- Analysis and refinement. It includes (a) analyse information obtained by interaction with customers, and constantly recognise customers' needs; (b) modify any planned marketing strategy in the light of analytical results, in order to obtain new business opportunities.

The measurement is based on a Likert 5-point scale, where 'Strongly agree' is 5 points, 'Agree' is 4 points, 'Fair' is 3 points, 'Disagree' is 2 points, and 'Strongly disagree' is 1 point.

\subsubsection{Measurement of business performance}

According to the literature review and the business characteristics of the high-tech industry, this study uses profit rate, growth of sales, product and service quality, customer maintenance rate, successful new products to market, and return on investment as measures of performance. These measures meet the following criteria: (1) the firm's profit rate is higher than that of rivals; (2) its sales growth is higher than that of rivals; (3) customers are more satisfied with the firm's products or service than that of rivals; (4) a high percentage of long-standing customers trade with the firm; (5) the firm has a higher percentage of successful new products to market than do its rivals; and (6) the firm's return on investment is higher than that of rivals.

The measurement is based on a Likert 5-point scale, where 'Strongly agree' is 5 points, 'Agree' is 4 points, 'Fair' is 3 points, 'Disagree' is 2 points, and 'Strongly disagree' is 1 point.

\subsubsection{Industry group and enterprise scale}

This paper examines industry characteristics using two metrics: industry group and enterprise scale.

- Industry group: According to the classification published in the 2010 Directory of Manufacturers in Science Park, the industries relate to integrated circuits, computers \& peripherals, communication, optical electronics, delicate machinery, and biotechnology.

- Enterprise scale: In accordance with the standards set by the Ministry of Economic Affairs, this paper classifies high-tech manufacturers into those that are large (over 200 employees) and small-to-medium (fewer than 200 employees). Both industry group and enterprise scale are measured using nominal scales.

\section{VALIDATION RESULTS}

\subsection{Correlation between type of business strategy and CRM activities}

This study divided business strategy (cost leadership, marketing differentiation, and innovative differentiation) into two groups: high and low implementation levels. According to the kind of CRM activity (knowledge discovery, marketing planning, customer interaction, and analysis and refinement) in the two groups, the researcher tries to find if there is a statistically significant at $a=0.05$ level. Analysis of the variance in the influence of business strategy on the implementation level of CRM activities is shown in Table 2. The result supports $\mathrm{H}_{1}$ : Different types of business strategy significantly and differently influence the implementation of CRM activities. The implementation level of cost leadership does not significantly and differently influence the implementation level of CRM activities. The implementation level of marketing differentiation and innovative differentiation significantly influence CRM activities. 


\begin{tabular}{|c|c|c|c|c|}
\hline CRM activities & Business strategy & Cost leadership & $\begin{array}{l}\text { Marketing } \\
\text { differentiation }\end{array}$ & $\begin{array}{l}\text { Innovative } \\
\text { differentiation }\end{array}$ \\
\hline \multirow{4}{*}{$\begin{array}{l}\text { Knowledge } \\
\text { discovery }\end{array}$} & Low $^{\#}$ & 3.65 & 3.39 & 3.57 \\
\hline & High $^{\#}$ & 3.85 & 3.91 & 3.98 \\
\hline & F-value & 1.38 & 8.97 & 8.22 \\
\hline & P-value & 0.243 & $0.004^{*}$ & $0.005^{*}$ \\
\hline \multirow{4}{*}{$\begin{array}{l}\text { Marketing } \\
\text { planning }\end{array}$} & Low $^{\#}$ & 3.76 & 3.52 & 3.65 \\
\hline & High $^{\#}$ & 3.95 & 4.01 & 4.11 \\
\hline & F-value & 1.51 & 9.71 & 13.3 \\
\hline & P-value & 0.222 & $0.003^{*}$ & $0.000^{*}$ \\
\hline \multirow{4}{*}{$\begin{array}{l}\text { Customer } \\
\text { interaction }\end{array}$} & Low $^{\#}$ & 3.65 & 3.43 & 3.44 \\
\hline & High $^{\#}$ & 3.87 & 3.91 & 4.12 \\
\hline & F-value & 1.43 & 6.64 & 22.71 \\
\hline & P-value & 0.236 & $0.012^{*}$ & $0.000^{*}$ \\
\hline \multirow{4}{*}{$\begin{array}{l}\text { Analysis and } \\
\text { refinement }\end{array}$} & Low $^{\#}$ & 3.86 & 3.62 & 3.67 \\
\hline & High $^{\#}$ & 3.94 & 4 & 4.13 \\
\hline & F-value & 0.21 & 4.31 & 9.91 \\
\hline & P-value & 0.645 & $0.041^{*}$ & $0.002^{*}$ \\
\hline
\end{tabular}

Note: \# Low: the average score in business strategy lower than 4; High: the average score in business strategy higher than $4 ;{ }^{*} \mathrm{p}<0.05$.

Table 2: Variance analysis of influence of the type of business strategy on CRM activities

\subsection{Correlation between information technology involvement and CRM activities}

This section probes the influence of information technology involvement on CRM activities. It divides information technology involvement (perceptions of employees, investment in hardware and software, personnel training, and information technology application) into two groups: high and low. According to the kinds of CRM activities (knowledge discovery, marketing planning, customer interaction, and analysis and refinement) in the two groups, the researcher tries to find if there is a statistically significant at $a=0.05$ level. Analysis of the variance in the influence of information technology involvement on CRM activities is shown in Table 3 . The result supports $\mathrm{H}_{2}$ : A higher information technology involvement leads to more significant and positive influence on the implementation level of CRM activities.

\subsection{Correlation between type of organisational culture and CRM activities}

This section probes the influence of the type of organisational culture on CRM activities. The study divides the type of organisational culture (rational, hierarchical, group and developmental culture) into two groups: high and low. According to the kinds of CRM activities (knowledge discovery, marketing planning, customer interaction, and analysis and refinement) in the two groups, the researcher tries to find if there is a statistically significant at $\mathrm{a}=0.05$ level. Analysis of the variance in the influence of organisational culture on CRM activities is shown in Table 4. The result rejects $\mathrm{H}_{3}$. Different types of organisational culture do not significantly influence the implementation level of CRM activities. However, the results reveal that a combination of organisational culture leads to a more significant influence on the implementation of CRM activities. Therefore, if firms can combine and use the characteristics of these four cultures, the implementation level of CRM activities will be significantly enhanced.

\subsection{Correlation between implementation level of CRM activities and business performance}

This study divides the implementation level of CRM activities (knowledge discovery, marketing planning, customer interaction, and analysis and refinement) into two groups: high and low. According to the kind of business performance in the two groups, the researcher tries to find if there is significant difference. Analysis of the variance in the influence of CRM activities on business performance is shown in Table 5. The result supports $\mathrm{H}_{4}$ : A higher implementation level of CRM activities leads to a more significant and more positive influence on business performance. 


\begin{tabular}{|c|c|c|c|c|c|}
\hline \multicolumn{2}{|l|}{ CRM activities } & $\begin{array}{l}\text { Perception of } \\
\text { employees }\end{array}$ & $\begin{array}{l}\text { Investment in } \\
\text { hardware and } \\
\text { software }\end{array}$ & $\begin{array}{l}\text { Personnel } \\
\text { training }\end{array}$ & $\begin{array}{l}\text { Degree of } \\
\text { information } \\
\text { technology } \\
\text { application }\end{array}$ \\
\hline \multirow{4}{*}{$\begin{array}{l}\text { Knowledge } \\
\text { discovery }\end{array}$} & Low $^{\#}$ & 3.35 & 3.55 & 3.63 & 3.53 \\
\hline & $\mathrm{High}^{\#}$ & 3.96 & 4.16 & 4.17 & 4.02 \\
\hline & F-value & 15.67 & 19.83 & 12.74 & 12.67 \\
\hline & P-value & $0.000^{*}$ & $0.000^{*}$ & $0.001^{*}$ & $0.001^{*}$ \\
\hline \multirow{4}{*}{$\begin{array}{l}\text { Marketing } \\
\text { planning }\end{array}$} & Low $^{\#}$ & 3.47 & 3.73 & 3.75 & 3.58 \\
\hline & High $^{\#}$ & 4.06 & 4.16 & 4.24 & 4.18 \\
\hline & F-value & 18.10 & 10.87 & 12.81 & 24.98 \\
\hline & P-value & $0.000^{*}$ & $0.001^{*}$ & $0.001^{*}$ & $0.000^{*}$ \\
\hline \multirow{4}{*}{$\begin{array}{l}\text { Customer } \\
\text { interaction }\end{array}$} & Low $^{\#}$ & 3.17 & 3.55 & 3.62 & 3.38 \\
\hline & High $^{\#}$ & 4.04 & 4.2 & 4.22 & 4.17 \\
\hline & F-value & 32.64 & 20.33 & 13.98 & 35.69 \\
\hline & P-value & $0.000^{*}$ & $0.000^{*}$ & $0.000^{*}$ & $0.000^{*}$ \\
\hline \multirow{4}{*}{$\begin{array}{l}\text { Analysis and } \\
\text { refinement }\end{array}$} & Low $^{\#}$ & 3.4 & 3.67 & 3.79 & 3.63 \\
\hline & High $^{\#}$ & 4.11 & 4.29 & 4.21 & 4.17 \\
\hline & F-value & 19.96 & 18.81 & 6.74 & 14.16 \\
\hline & P-value & $0.000^{*}$ & $0.000^{*}$ & $0.011^{*}$ & $0.000^{*}$ \\
\hline
\end{tabular}

Note: \# Low: the average score in the degrees of information technology involvement lower than 4; High: the average score in the degrees of information technology involvement higher than $4 ;{ }^{*} p<0.05$.

Table 3: Variance analysis of the influence of the degrees of information technology involvement on the degree of implementation of CRM activities

\begin{tabular}{llcccc}
\hline CRM activities & $\begin{array}{l}\text { Organisational } \\
\text { cultures }\end{array}$ & $\begin{array}{l}\text { Rational } \\
\text { culture }\end{array}$ & $\begin{array}{l}\text { Hierarchical } \\
\text { culture }\end{array}$ & $\begin{array}{l}\text { Group } \\
\text { culture }\end{array}$ & $\begin{array}{l}\text { Developmental } \\
\text { culture }\end{array}$ \\
\hline Knowledge & Low $^{\#}$ & 3.39 & 3.56 & 3.57 & 3.45 \\
discovery & High $^{\#}$ & 4.02 & 4.07 & 3.98 & 4.06 \\
& $F^{-v a l u e ~}$ & 20.38 & 14.06 & 7.97 & 20.63 \\
& P-value & $0.000^{*}$ & $0.000^{*}$ & $0.006^{*}$ & $0.000^{*}$ \\
\hline Marketing & Low $^{\#}$ & 3.52 & 3.71 & 3.67 & 3.58 \\
planning & High & 4.11 & 4.12 & 4.08 & 4.15 \\
& F-value & 21.82 & 9.57 & 9.9 & 22.04 \\
& P-value & $0.000^{*}$ & $0.003^{*}$ & $0.002^{*}$ & $0.000^{*}$ \\
\hline Customer & Low & 3.39 & 3.61 & 3.5 & 3.4 \\
interaction & High & 4.04 & 4.04 & 4.05 & 4.12 \\
& F-value & 18.54 & 7.68 & 13.62 & 26.54 \\
& P-value & $0.000^{*}$ & $0.007^{*}$ & $0.000^{*}$ & $0.000^{*}$ \\
\hline Analysis and & Low & 3.59 & 3.59 & 3.66 & 3.53 \\
refinement & High & 4.1 & 3.97 & 4.13 & 4.22 \\
& F-value & 11.29 & 6.75 & 10.18 & 25.28 \\
& P-value & $0.001^{*}$ & $0.011^{*}$ & $0.002^{*}$ & $0.000^{*}$ \\
\hline
\end{tabular}

Note: \# Low: the average score in the degrees of organisational cultures lower than 4; High: the average score in the degrees of organisational cultures higher than $4 ;{ }^{*} \mathrm{p}<0.05$.

Table 4: Variance analysis of the influence of the degrees of organisational cultures on the degree of implementation of CRM activities

\begin{tabular}{lcccc}
\hline \multirow{2}{*}{ CRM activities } & \multicolumn{4}{c}{ Business performance } \\
\cline { 2 - 5 } & Low $^{\#}$ & High $^{\#}$ & F-value & P-value \\
\hline Knowledge discovery & 3.16 & 3.74 & 13.93 & $0.000^{*}$ \\
Marketing planning & 3.00 & 3.80 & 29.68 & $0.000^{*}$ \\
Customer interaction & 3.10 & 3.74 & 16.59 & $0.000^{*}$ \\
Analysis and refinement & 2.89 & 3.75 & 30.69 & $0.000^{*}$ \\
\hline
\end{tabular}

Note: \# Low: the average score in customer relationship management activities lower than 4; High: the average score in customer relationship management activities higher than $4 ;^{*} p<0.05$.

Table 5: Variance analysis of the influence of the degrees of implementations of CRM activities on business performance 


\subsection{The influence of executive degree of manufacturers' CRM activities with different industry characteristics on business performance}

This section explores the influence of the executive degree of manufacturers' CRM activities with different industry characteristics (enterprise scale and industry group) on business performance. The results in Table 6 show that industry characteristics do not have a significant influence on the executive degree of customer relationship management activities. Table 7 reveals that the manufacturers' industry group and enterprise scale do not significantly influence business performance. As seen above, for manufacturers with different industry characteristics, the executive degree of customer relationship management activities do not reveal a significant impact on business performance.

\begin{tabular}{lccccc}
\hline \multirow{2}{*}{ CRM activities } & \multicolumn{2}{c}{ Enterprise scale } & & \multicolumn{2}{c}{ Industry group } \\
\cline { 2 - 3 } \cline { 5 - 6 } & F-value & P-value & & F-value & P-value \\
\hline Knowledge discovery & 0.305 & 0.582 & & 0.587 & 0.710 \\
Marketing planning & 0.385 & 0.537 & & 0.694 & 0.630 \\
Customer interaction & 1.135 & 0.290 & & 1.124 & 0.355 \\
Analysis and refinement & 0.038 & 0.846 & & 0.758 & 0.583 \\
\hline
\end{tabular}

Table 6: ANOVA of industry characteristics (enterprise scale and industry group) and executive involvement in each phase of CRM activities

\begin{tabular}{|c|c|c|c|c|}
\hline & \multicolumn{2}{|c|}{ Enterprise scale } & \multicolumn{2}{|c|}{ Industry group } \\
\hline & F-value & P-value & F-value & P-value \\
\hline Business performance & 0.289 & 0.592 & 0.743 & 0.594 \\
\hline
\end{tabular}

Table 7: ANOVA for industry characteristics (enterprise scale and industry group) and business performance

\section{DISCUSSION AND CONCLUSIONS}

Few empirical studies include business strategy, information technology involvement, and organisational culture in CRM activities to examine their influences on business performance. Therefore, by treating the high-tech industry as the subject, this study has explored the correlations between type of business strategy, information technology involvement, type of organisational culture, implementation level of CRM activities, and business performance. The findings demonstrate that different types of business strategy significantly and differently influence the implementation of CRM activities. A higher degree of differentiation strategy (marketing differentiation or innovative differentiation) leads to a more significant influence on the implementation of CRM activities. A higher information technology involvement and organisational culture significantly and positively influence the implementation level of CRM activities; a higher implementation level of CRM activities significantly and positively influences business performance. However, different types of organisational culture do not significantly influence the implementation level of CRM activities.

This paper suggests that, in order to increase business performance, firms should enhance differentiation strategies (marketing differentiation and innovative differentiation), increase information technology involvement and implementation of CRM activities, combine and use the characteristics of the four cultures in the competing values framework, and develop the implementation level of these four cultures.

The study only focused on high-tech firms. Future studies could conduct an empirical analysis of other industries to examine any correlation between type of business strategy, information technology involvement, type of organisational culture, implementation level of CRM activities, and business performance in the organisations in different industries, and so acquire more complete research findings. 


\section{ACKNOWLEDGEMENT}

The authors thank the National Science Council of Taiwan (Republic of China) for financially supporting this research under Project No. NSC 99-2221-E-233-003-.

\section{REFERENCES}

[1] Agarwal, A., Harding, D.P. \& Schumacher, J.R. 2004. Organizing for CRM. McKinsey Quarterly, 3, 80-91.

[2] Baer, M. \& Frese, M. 2003. Innovation is not enough: Climates for initiative and psychological safety, process innovations, and firm performance. Journal of Organizational Behavior, 24(1), 45-68.

[3] Baker, W.E. \& Sinkula, J.M. 1999. Learning orientation, market orientation, and innovation: Integrating and extending models of organizational performance. J ournal of Market Focused Management, 4(4), 295-308.

[4] Van Bentum, R. \& Stone, M. 2005. Customer relationship management and the impact of corporate culture - A European study. Database Marketing \& Customer Strategy Management, 13(1), 28-54.

[5] Bose, R. 2002. Customer relationship management: Key components for IT success. Industrial Management \& Data Systems, 102(2), 89-97.

[6] Caldwell, J. 2000. Building a sustainable e-business CRM strategy. Agency Sales Magazine, 30(5), 23-27.

[7] Chen, I.J. \& Popovich, K. 2003. Understanding customer relationship management (CRM): People, process and technology. Business Process Management J ournal, 9 (5), 672-688.

[8] Christy, R., Oliver, G. \& Penn, J. 1996. Relationship marketing in consumer markets, J ournal of Marketing Management, 12(12), 175-187.

[9] Chung, Y.C., Hsu, Y.W. \& Tsai, C.H. 2010a. Research on correlation between information technology involvement, market orientation, innovative activities implementations and firm performances in Taiwan's Science Industrial Park. Information Technology J ournal, 9(4): 621-631.

[10] Chung, Y.C., Hsu, Y.W. \& Tsai, C.H. 2010b. Research on the correlation between implementation strategies of TQM, organizational culture, TQM activities and operational performance in high-tech firms. Information Technology J ournal, 9(8), 1696-1705.

[11] Cooper, B.L., Watson, H.J., Wixom, B.H. \& Goodhue, D.L. 2000. Data warehousing supports corporate strategy at First American Corporation. MIS Quarterly, 24(4), 547-567.

[12] Tolfo, C. \& Wazlawick, R.S. 2008. The Influence of organizational culture on the adoption of extreme programming. J ournal of Systems and Software, 81(11), 1955-67.

[13] Croteau, A.M. \& Bergeron, F. 2001. An information technology trilogy: Business strategy, technological deployment and organizational performance. Journal of Strategic Information Systems, 10(2), 77-99.

[14] Curry, A. \& Kkolou, E. 2004. Evaluating CRM to contribute to TQM improvement - a cross case comparison. The TQM Magazine, 16(5), 314-324.

[15] Deshpande, R. \& Farley, J.U. 1999. Executive insights: Corporate culture and market orientation: Comparing Indian and Japanese firms. J ournal of International Marketing, 7(4), 111127.

[16] Duffy, J. 2000. The KM technology infrastructure. Information Management J ournal, 34(2), 6266.

[17] Durand, R. \& Coeurderoy, R. 2001, Age, order of entry, strategic orientation, and organizational performance. J ournal of Business Venturing, 16 (5), 471-494.

[18] Farrell, M.A. 2000. Developing a market-oriented learning organisation. Australian J ournal of Management, 25(2), 201-223.

[19] Jones, G. R. \& George, J.M. 2007. Essentials of contemporary management ( ${ }^{\text {nd }}$ ed.). Boston: McGraw-Hill.

[20] Kalakota, R. \& Robinson, M. 1999. e-Business: Roadmap for success. Addison-Wesley Longman.

[21] Kalakota, R. \& Robinson, M. 2001. E-Business 2.0: Roadmap for success (2 $2^{\text {nd }}$ ed.). Boston, MA: Addison-Wesley.

[22] Kandell, J. 2000. CRM, ERM one-to-one decoding relationship management theory and technology. Trusts \& Estates, 139(4), 49-53.

[23] Kirca, A.H., Jayachandran, S. \& Bearden, W.O. 2005. Market orientation: A meta-analytic review and assessment of its antecedents and impact on performance. J ournal of Marketing, 69 (2), 24-41.

[24] Ko, E., Kim, S.H., Kim, M. \& Woo, J.Y. 2008. Organizational characteristics and the CRM Nadoption process. J ournal of Business Research, 61(1), 65-74.

[25] Ko, E., Kincade, D.H. \& Brown, J.R. 2000. Impact of business strategy on the adoption of quick response technologies: The apparel industry experience. International J ournal of Operation \& Production Management, 20 (9), 1093-1111. 
[26] Krishnan, M.S., Ramaswamy, V., Meyers, M.C. \& Damien, P. 1999. Customer satisfaction for financial services: The role of products, services, and information technology. Management Science, 45(9), 1194-1209.

[27] Lee, S.K.J. \& Yu, K. 2004. Corporate culture and organizational performance. Journal of Managerial Psychology, 19(4), 340-359.

[28] Lee M.H. 2006. The impact of IT investment, communication, innovation in participative budgeting systems on performance: Hotel industry in Taiwan as example. M.S. Thesis, Institute of Business Administration, National Dong Hwa University.

[29] Lin C.S. 2006. The influence of organizational performance by the indulged depth of operational strategy and customer relationship management. M.S. Thesis, Executive Master of Business Administration.

[30] Li, X. 2008. Study on the influence of enterprise culture's reform on CRM. International J ournal of Business and Management, 3(2), 23-26.

[31] Lynch D.F., Keller, S.B. \& Ozment, J. 2000. The effects of logistics capabilities and strategy on firm performance. J ournal of Business Logistics, 21(2), 47-67.

[32] Meso, P. \& Smith, R. 2000. A resource-based view of organizational knowledge management system. J ournal of Knowledge Management, 4(3), 224-234.

[33] Miles, R.E. \& Snow, C.C. 1978. Organizational strategy, structure and process. New York: McGraw-Hill.

[34] Miller, J. \& Doyle, B.A 1987. Measuring the effectiveness of computer-based information systems in the financial services sector. MIS Quarterly, 11(1), 107-124.

[35] Miller, D. 1988. Relating Porter's business strategies to environment and structure: analysis and performance implications. Academy of Management J ournal, 31(2), 280-308.

[36] Nunnally, J. 1978. Psychometric theory ( $2^{\text {nd }}$ ed. $)$. New York: McGraw-Hill.

[37] Parker, R. \& Bradley, L. 2000. Organizational culture in the public sector: Evidence from six organizations. International J ournal of Public Sector Management, 13(2), 125-141.

[38] Pekala, N. 2001. Merger they wrote: Avoiding a corporate culture collision. J ournal of Property Management, 66(3), 32-36.

[39] Pelham, A.M. 2000. Market orientation and other potential influences on performance in small and medium-sized manufacturing firms. J ournal of Small Business Management, 38(1), 48-67.

[40] Peppard, J. 2000. Customer relationship management (CRM) in financial services. European Management J ournal, 18 (3), 312-327.

[41] Peppers, D., Rogers, M. \& Dorf, B. 1999. Is your company ready for one-to-one marketing? Harvard Business Review, 77(1), 151-160.

[42] Porter M. E. 1980. Competitive strategy. New York: The Free Press.

[43] Porter, M.E. \& Miller, V.E. 1985. How information gives you competitive advantage. Harvard Business Review, 63(4), 149-160.

[44] Prajogo, D.I. \& Sohal, A.S. 2006. The relationship between organization strategy, total quality management (TQM), and organization performance - The mediating role of TQM. European J ournal of Operational Research, 168(1), 35-50.

[45] Quinn, R.E. 1988. Beyond rational management: Mastering paradoxes and competing demands of high performance. Jossey-Bass, San Francisco.

[46] Ratcliff, P. 2000. Managing deeper relationship. Mortgage Banking, 60(6), 94-100.

[47] Roberts, C.B. 1996. The impact of information technology on the management of system design. Technology in Society, 18(3), 333-355.

[48] Robbins, S.P. 2001. Organizational behavior $\left(9^{\text {th }}\right.$ ed. $)$. Prentice Hall, Upper Saddle River, N.J.

[49] Sakaguchi, T. \& Dibrell, C. 1998. Measurement of the intensity of global information technology usage: Quantitizing the value of a firm's information technology. Industrial Management \& Data Systems, 98(8): 380-394.

[50] Saraph, J.V., Benson, P.G. \& Schroeder, R.G. 1989. An instrument for measuring the critical factors of quality management. Decision Sciences, 20(4), 810-829.

[51] Shoemaker, M.E. 2001. A framework for examining IT-enabled market relationships. J ournal of Personal Selling and Sales Management, 21 (2), 177-185.

[52] Shrader, R.C. 2001. Collaboration and performance in foreign markets: The case of young hightechnology manufacturing firms. Academy of Management J ournal, 44(1), 45-60.

[53] Slater, S.F. \& Narver, J.C. 2000. The positive effect of a market orientation on business profitability: A balanced replication. J ournal of Business Research, 48(1), 69-73.

[54] Sohal, A.S., Moss, S. \& Ng, L. 2001. Comparing IT success in manufacturing and service industries. International J ournal of Operations and Production Management, 21(1/2), 30-45.

[55] Song, X.M., Neeley, S.M. \& Zhao, Y. 1996. Managing R\&D-marketing integration in the new product development processes. Industrial Marketing Management, 25(6), 545-553.

[56] Su, C.T., Li, S.C. \& Su, C.H. 2003. An empirical study of the Taiwan National Quality Award causal model. TQM \& Business Excellence, 14(8), 875-893.

[57] Swift, R.S. 2001. Accelerating customer relationship: Using CRM and relationship technology. Prentice Hall, New Jersey. 
[58] Tiwana, A. 2001. The essential guide to knowledge management: E-business and CRM applications. Upper Saddle River, NJ: Prentice Hall PTR.

[59] Tippins, M.J. \& Sohi, R.S. 2003. IT competency and firm performance: Is organizational learning a missing link? Strategic Management J ournal, 24(8), 745-761.

[60] Wallach, E.J. 1983. Individuals and organizations: The cultural match. Training and Development J ournal, 37(2), 29-36.

[61] Yamin, S., Mavondo, F., Gunasekaran, A. \& Sarros, J.C. 1997. A study of competitive strategy, organizational innovation and organizational performance among Australian manufacturing companies. International J ournal of Production Economics, 52(2), 161-172.

[62] Yim, F.H, Anderson, R.E. \& Swaminathan, S. 2004. Customer relationship management: Its dimensions and effect on customer outcomes. J ournal of Personal Selling \& Sales Management, 24(4), 263-278. 